no consistent effect of treatment. We believed the message to be clear without further sophisticated statistics.

(5) We are a little confused by the comment on nonparametric tests. They do avoid the assumption of an underlying normal distribution and that was all we were claiming.

In conclusion, we heartily concur with $\mathrm{Dr}$ James's appeal that care is taken with statistical procedures. This was certainly the case with our study.

A V SWaN

St Thomas's Hospital,

C M WILES

London SE1 7EH

\section{R A Clarke}

\section{Depertapent of Neurotogy, \\ Thipe Cross Hospital,} i Baker RJ, Netder. JA. The GLIM system. Manual for release 3.
Qxford: Wumerical Agorithms Group, 1976.

Sip,-The proponents of hyperbaric oxygen in the treatment of multiple sclerosis appear to be at loggerbeads, Dr John Bolt and colleagues (8 March, p 1 ) claim improvement or stabilisation of chronic disease in open trials, which are hotoriously fallibie. Dr P B James (p 692) states that even randomised double blind controlled trials in chronic disease are "a travesty of the scientific method" and believes that benefit migh be obtained in acure relapse but produces no personal evidence to support this claim. Emotiona involvemerit in the welfare of patients with multiple sclerosis or in methods designed to improve their lot is difficult to avoid, but does not lead to clear thinking.

W B MATTHEWS

Department of Clinical Neurology,

The Radcliffe Infirmary, Oxford

Alcoholic ketoacidosis: an underdiagnosed condition?

SIR,-The interesting article by Dr C J Thompson and colleagues (15 February, $p$ 463) focuses on what we believe to be just one extreme of a mixed acid-base disorder with which binge drinkers can present. Most alcoholics will present with much milder acidosis ${ }^{12}$ than the two cases described because of concomitant metabolic alkalosis induced by vomiting. The acid-base state on admission reflects the relative severity of ketoacidosis and metabolic alkalosis.

We recently saw a patient who, in spite of severe ketoacidosis, presented with an alkalaemia and a high anion gap. This 38 year old male alcoholic had been on a binge for several days and was vomiting frequently for two days immediately before admission. He complained of epigastric pain, sweating and muscle cramps. He was clinically dehydrated but alert and well oriented. Pulse rate was 100 beats/min and blood pressure $120 / 60 \mathrm{~mm} \mathrm{Hg}$. Laboratory findings were: serum sodium concentration $138 \mathrm{mmol}(\mathrm{mEq}) / 1$, potassium $3.3 \mathrm{mmo}$ $(\mathrm{mEq}) / 1$ chloride $60 \mathrm{mmol}(\mathrm{mEq}) / 1$, total carbon dioxide $36 \mathrm{mmol}(\mathrm{mEq}) / \mathrm{l}$, urea $8.8 \mathrm{mmol} / \mathrm{l}$ $(52.9 \mathrm{mg} / 100 \mathrm{ml})$, giving an anion gap of $42 \mathrm{mmol} / \mathrm{l}$. Plasma glucose was $8.6 \mathrm{mmol} /$ $(155 \mathrm{mg} / 100 \mathrm{ml}), \beta$ hydroxybutyrate $7.6 \mathrm{mmol} / \mathrm{l}$ and lactate $1.1 \mathrm{mmol} / 1(9.9 \mathrm{mg} / 100 \mathrm{ml})$. Urine ketones were strongly positive on nitroprusside testing. On admission $\mathrm{pH}$ was $7 \cdot 58, \mathrm{PCO}_{2} 5 \cdot 9 \mathrm{kPa}$ $(44 \mathrm{~mm} \mathrm{Hg})$, base excess $+17 \mathrm{mmol}(\mathrm{mEq}) / 1$, and $\mathrm{Po}_{2} 10.4 \mathrm{kPa}(78 \mathrm{~mm} \mathrm{Hg})$. Serum calcium was $2.25 \mathrm{mmol} / 1(4.9 \mathrm{mEq} / \mathrm{l})$, albumin $46 \mathrm{~g} / \mathrm{l}$, amylase $310 \mathrm{IU} / \mathrm{l}$, and mean cell volume $114 \mathrm{fl}$. Serum creatine kinase was raised over three days at 500 ,
445 , and $485 \mathrm{IU} / 1$, but there was no electrocardiographic evidence of myocardial infarction. Thyroid function was normal. After fluid replacement the $\mathrm{pH}$ and electrolytes rapidly became normal. The patient discharged himself on the third day.

We would thus like to extend the conclusions of Dr Thompson and colleagues and point out that alcoholic ketoacidosis as a pathological process should be considered in akcoholic binge drinkers, irrespective of the actual $\mathrm{pH}$ on admission.

We thank Dr M Soukop for allowing us to present data on his patient.

Department of Pathological Biochemistry,

Western Infirmary, Glasgow G11 6NT

1 Halperin ML, Hammeke M, Josse RG, Jungas RL. Metabolic acidosis in the alcoholic: a pathophysiologic approach. Merabo lism 1983:32:308-15.

2 Fulop $M$, Hoberman D. Diabetic ketoacidosis and alcoholic ketoacidosis. Ann Intem Med 1979;91:796-7.

\section{Internal urinary sphincter in maintenance of} female continence

SIR,-Dr E Versi and colleagues (18 January, p 166) question the importance of the internal urinary sphincter for maintaining female continence and indicate that contraction of its muscles could not close the neck of the bladder. ${ }^{1}$ Recent structural studies support their conclusions by suggesting a more plausible mechanism for the maintenance of female continence and the control of micturition. ${ }^{2}$

The urethra is a collapsed tube which opens only during micturition. ${ }^{34}$ Hence it acts as a valve to retain urine unless the pressure in the bladder is excessive. Contraction of the longitudinal muscles of the urethra will, however, open the lumen and so initiate micturition. ${ }^{2}$ The flow of urine and longitudinal tension in the muscles usually maintain the lumen in its open position until the bladder is voided. The urethra then closes by its own elasticity. ${ }^{23}$ Contraction of circular muscles can close the urethra, interrupting the flow of urine and preventing micturition during sudden increases in abdominal pressure, such as when coughing.

This mechanism is physically plausible and accords with experience of the control of micturition in both men and women. Continence is maintained by the passive elasticity of the urethra and so does not require expenditure of energy for active muscular control. Only when the pressure rises excessively does urine leak out, and even then this can usually be prevented, presumably by resting muscle tone or contraction of the circular muscles. Contraction of the longitudinal muscles and longitudinal urethral forces arising from detrusor contraction are important because they initiate micturition, which then normally continues until the bladder is voided.

The mechanism of continence is, therefore energetically efficient because it does not depend on continuous muscular activity but is subject to various muscular controls. Thus it is not surprising that an incompetent bladder neck does not result in incontinence.

D S HICKEY

Department of Medical Biophysics,

D W L HukINS

University of Manchester

Manchester M13 9PT

1 Gosling JA, Dixon JS, Landon RG. The autonomic innervation of the male and female bladder neck in proximal urethra. $\mathcal{f}$ Urol 1977;118:302-5.

Hickey DS, Phillips JI, Hukins DWL. Arrangement of collage fibrils and muscle fibres in the female urethra and their fibrils and muscle fibres in the female urethra and their implica

Pullan BR, Phillips JI, Hickey DS. Urethral lumen cros sectional shape: its radiological determination and relationship to function. Br $\mathcal{J}$ Urol 1982;54:399-407.

Hickey DS, Fonda D, Klein JA, Brocklehurst JC. Algorithm for the determination of projected urethral lumen cross sections and shape functions. $\mathcal{f}$ Urol 1985;132:1044-7.

\section{A boost for clinical research}

SIR,-With all due respect to the good people who have laboured so prodigiously at the Northwick Park Clinical Research Centre (8 February, p 416) it has been the conviction of many for some time past that planned centres of excellence frequently lack that happy confluence of the right people in the right place at the right time that is the basis of the success of centres with mone spontaneours origins. The preoccupation of the hosplitel clinicians at Northwick Park with "common diseases" would appear to be less of a problem than the failure of the MRC scientists to recognise epidemiological opportunities on their doorstep. Paradoxically another problem for epidemiological research was well illustrated by the MRC's randomised controlled trial of mild to moderate hypertension. ${ }^{1}$ This had to depend on the rest of the country to provide both suitable participants and appropriate denominators. Now it is proposed to relocate the MRC in another denominatorless institution. The Royal Postgraduate Medical School does not have a clearly identified catchment area, and even if it had it would not be representative of the rest of the country.

In these circumstances it is not a matter of whether the CRC should move to Hammersmith or the Royal Postgraduate Medical School to Northwick Park, but rather where the centre can find a place outside London from which clinical epidemiology could be more effectively practised. The MRC could do no better than follow the example of Sir Dugald Baird many years ago when he recognised the inadequacy of London as a base for access to truly representative clinical and epidemiological cases. His decision was to move himself lock, stock, and barrel to Aberdeen.

Perhaps more cogently, both the MRC and CRC should catch up with the times and recognise the paramount need to develop clinical epidemiology. Where better could they site themselves than in any one of the five Scottish university cities? With its population of five and a quarter million Scotland has a denominator of the right size, a superb health information system, outstanding academic and clinical leadership, and a centuries old reputation as a pioneer in medical research and clinical practice.

Siting anything in London these days is an outmoded concept, still based on the same misplaced sense of what really matters as influenced the decision to build the Channel tunnel. Like oil and the civil service, devolution is what the situation demands and what the whole country should insist on. Any plan that the MRC may have in mind should be placed in abeyance until a properly constituted body reviews the options for the very much more effective deployment of some very scarce public resources.

VICTOR M HAWTHORNE

Department of Epidemiology,

University of Michigan, School of Public Health,

Ann Arbor, Michigan 48109, USA

1 Medical Research Council Working Party. MRC trial of treatment of mild to moderate hypertension. BrMed f 1985;291:97104

\section{Correction}

Profound hypophosphataemia in patients collapsing after a "fun run"

We regret that two errors occurred in this letter by Professor D R Wilkie (8 March, p 692). In the first sentence of the first paragraph the rate of absorption of inorganic phosphate should have read $5 \mathrm{mmol} / \mathrm{l} / \mathrm{min}$, not $5 \mathrm{mmol} / \mathrm{min}$. In the text the references were wrongly numbered as 2-5; they should have been 1-4. 